\title{
THE HISTORICAL BACKGROUND OF ALIMONY LAW AND ITS PRESENT STATUTORY STRUCTURE
}

\author{
Chestrr G. Vernier* and John B. Hurlbut**
}

\section{Alimony in the Ecclestasticat Courts}

Alimony in the unwritten law of England developed as a part of the law of divorce in the Ecclesiastical courts. Although that alimony with which we are now familiar is found in an essentially different background, the imprint of Ecclesiastical practice is readily perceived in both our case and statutory law. Prior to 1857 , the Ecclesiastical courts applying for the most part the Canon Law exercised jurisdiction of matrimonial causes, ${ }^{1}$ and consequently of the allowance of alimony. ${ }^{2}$ Marriage was thought to be a sacrament and indissoluble. ${ }^{3}$ Divorce a mensa et thoro was granted for adultery and cruelty. "This legal monstrosity, today called "judicial separation" and little desired by litigants, did not purport to dissolve the marriage but on the contrary contemplated the possibility of reconciliation. The Ecclesiastical courts also pronounced nullity sentences, peculiarly called divorce a vinculo matri-

A.B., 1903, Butler College; J.D., I907, University of Chicago. Professor of Law, Stanford University. Author of Cases on Marriage and Divorce (West Publishing Co. 1912); American Family Laws, Vols. I to $V$ and Supplement (Stanford University Press, I93 1 to 1938); and numerous articles in legal magazines.

* A.B., I928, University of California at Los Angeles; A.M., r929, Stanford University; LL.B., I934, Stanford University. Associate Professor of Law, Stanford University. Co-author of Vol. III, American Family Latus (Stanford University Press, 1935).

'On the general subject of divorce in the English law, see Bryce, Marriage and Divorce under the Roman and English Law, 3 Select Essars in ANglo AMrrican History (I909), 782, 822 ff.; I HoldsWORTH, A History of THE ENGLish LAw (r903), 389 f.; 12 id. (1938) 685; KITcheN, A History OF Divorce (Ig12) c. IX; 2 Howard, A History of Matrimonial Institutions (1904) 3 ff.; First Report of the Commissioners to INQUire into the LAw of Divorce (I853) 40 PARI. Reports 1852-I 853; Report of the Royal Comimission on Divorce and Matrimonial Causes (igi2) i 8-20 Pari. Reports rgiz-igr3.

${ }^{2}$ During the Cromwellian era and the temporary abolition of the ecclesiastical jurisdiction, it seems that the High Court of Chancery entertained alimony petitions. Setaro, A History of the English Ecclesiastical Law (1908) 18 Boston Univ. L. Rev. 102, I23; I Bishop, Marriage, Divorce and Separatton (189r) $\$ 1394$.

3 The power to dissolve a valid marriage for adultery was claimed by leading ecclesiastics in the sixteenth century, and it is said that for some years prior to the decision in Rye v. Fuljambe, Moore 683 (1602), men acted upon the belief that divorce for adultery left the parties free to remarry. See de Montmorency, An Introduction to the History of Divorce, Report of THE ROYal COMmisston on Drvorce AND Mitrimonial Causes (1912) 20 ParL. Reports x912-1913, app. I, p. I8; Dibden, Notes on the Reformatio Legum, id. p. 42; 2 Howard, op. cit. supra note I, 76 ff; MacQueEn, The Appellate JuRisdiction OF THE HOUSE OF LORDS ( 5842$) 467 f$.

' 2 Burn, The Ecclesiastical Law (9th ed. i842) 501 1, ff.; Poynter, Doctrine and Practice of the Ecclesiastical Courrs in Doctor's Commons (2d ed. 1836) 64 ff. (13 Law Lib.) 
monii, which declared the marriage invalid $a b$ initio because of some impediment existing at the time of the marriage. ${ }^{5}$ For the dissolution of a valid marriage, resort was had to absolute divorce by private Act of Parliament. ${ }^{6}$ This "privilege of the aristocracy" was the precursor of the Divorce Act of $1857^{7}$ which ousted the Ecclesiastical courts of divorce jurisdiction, and which established the absolute divorce by judicial decree. The latter had already been accomplished in most of the American states. $^{8}$

Permanent alimony in the unwritten law is an incident of the Ecclesiastical divorce $a$ mensa et thoro. ${ }^{9}$ In some respects the setting in which the alimony order was made seems rather remote today. Then, as now, pecuniary provision for the injured wife was necessary as a matter of social economy. Inequality of economic opportunity as a fact was not obscured by modern notions of "equal rights." Her technical legal status permitted such relief without resort to novel doctrines. In legal contemplation, the marital tie upon which the husband's legal duty to maintain her rested was not severed by the divorce decree. There were, however, other considerations present. The discriminatory common law scheme of marital property rights was in full bloom. Only very serious and aggravated types of marital transgressions entitled the wife to divorce. It is no wonder that her application for permanent alimony was treated with sympathy, and with liberality when the circumstances permitted liberality. ${ }^{10}$

The primary object of the order for permanent alimony was to provide continuing maintenance for the wife. In form at least there was no pretense of effecting a division of property. The order was invariably for periodic payments, ${ }^{11}$ usually commencing at the date of the divorce sentence. ${ }^{12}$ The amount of the award rested in broad discretion of the Ecclesiastical judge. ${ }^{13}$ The ultimate considerations, of course,

\footnotetext{
$5_{2}$ Burn, op. cit. supra note 4, $500 \mathrm{~d}$ ff.; Poxnter, op. cit. supra note $4,30 \mathrm{ff}$. Prior to legislation of 1540 (32 HEN. VIII, c. 38 ) the nullity sentence in some measure served as a practical substitute for absolute divorce by reason of the application of grotesque doctrines regarding impediment by precontract and the forbidden degree of consanguinity and affinity. See 2 Pollock AND Maitrand, Histony of THE ENGLISH LAW (2d ed. 1899) 385 ff; 2 HowArd, op. cit. supra note 1 , at 54 ff.

"Before $17 \times 5$ only 5 such bilis were known, between 1715 and 1775 there were 60 , between 1775 and $I 800$ there were 74, between $I 800$ and 1850 there were 90." I HoLDsworTh, op. cit. supra note I, at 390 n. 6. See MacQueEN, op. cit. supra note 3, at 466 ff.; 2 Howard, op. cit. supra note 1 , at 102 f.

20 \& $2 \mathrm{I}$ VICT. c. 85 . 33 HOWARD, op. cit. stipra note $\mathrm{I}$, at 3 ff.

${ }^{\circ}$ Cursory statements of the law of alimony in the ecclesiastical courts will be found in AuLipre, PARERGON (I726) 58 ff; 2 BRIGHT, HuSBAND AND WIFE (1849) 357 ff.; 2 BURN, op. cit. stipra note 4, at 505 ff; Godolphin, Repertorium Canonicum (3d ed. 1687 ) 508 f.; Ponnter, op. cit. supra note 4 , at $85 f f$.

10 "The delinquency of the husband is now established; the wife is the injured party; she is separated from the comfort of matrimonial society, from the society of her family, not by Act of Providence, but by misconduct of her husband; she must be liberally supported." Sir John Nicholl in Otway v. Otway, 2 Phill. Ecc. ro9, 161 Eng. Repr. 1092, 1093 (1813). There are no regular reports of the ecclesiastical courts prior to the three volumes of Phillmore beginning in 1809 . There is no reason to believe that the reported decisions do not reflect the traditional attitude of the ecclesiastical judges.

11 "Alimony is allotted for the maintenance of a wife from year to year." Wilson v. Wilson, 3 Hag. Ecc. 329, 162 Eng. Repr. I175 (note) (1830).

12 Cook v. Cook, 2 Phill. Ecc. 40, I6r Eng. Repr. ro72 (1812); Kempe v. Kempe, I Hag. Ecc. 532, 162 Eng. Repr. 668 (1828).

18 ". . . it is only upon a strong difference of opinion where the Court of Appeal would be disposed to disturb the sentence." Cooke v. Cooke, supra note 12 , at 4r, 16r Eng. Repr. 1072.
} 
were the needs of the wife and the ability of the husband to pay. ${ }^{14}$ The marital delinquency of the husband standing established, the amount was usually greater than that given as temporary alimony. ${ }^{15}$ While provision for the custody and maintenance of the children was without the province of the Ecclesiastical judge, ${ }^{10}$ the husband's obligation to support the children was not ignored in fixing the amount which he could appropriately be called upon to pay for the wife's support.77 Actually, however, the order for permanent alimony involved more than a mere judicial measurement of the husband's legal duty as husband to support the wife. If he acquired wealth from the wife by virtue of the marriage, he could not be compelled to disgorge, but that fact was of influence in fixing the amount of the award. ${ }^{18}$ Finally, in the minds of some of the judges at least, the notion of punishment depending upon the degree of the husband's moral delinquency played some part in the process. ${ }^{19}$ By balancing the above considerations the wife might be allotted as much as one-half of the combined income of the spouses, and often as much as one-third. ${ }^{20}$

While apparently there is no reported precedent in the Ecclesiastical courts on the matter, ${ }^{21}$ it has been assumed that permanent alimony to the guilty wife against whom the husband secured a separation was judicially unthinkable. ${ }^{22}$ This unenlightened view, totally blind to the fact that a guilty wife may starve as quickly as an innocent one, found technical justification in the theory that the husband's duty to support continued only so long as she cohabited with him or lived apart because of his misconduct. In this respect Parliamentary precedent is significant. As the legislative divorce grew in popularity, it became common practice for Parliament to insist

\footnotetext{
1s The wife was said to be entitled to a "comfortable subsistence in proportion to her husband's income," Kempe v, Kempe, stupa note 12, at 533, I62 Eng. Repr. 668, 669, and "consistent with her station in society." Durant v. Durant, I Hag. Ecc. 528, 53I, I62 Eng. Repr. 667, 668 (I826). If the wife was secured in a separate income, the joint income of the spouses was invariably made the basis for computing the amount of permanent alimony.

${ }^{15}$ Cooke v. Cooke, supra note 12; Otway v. Otway, supra note 10; Kempe v. Kempe, supra note I2.

${ }^{10}$ An indirect control over the custody of children was exercised, however, by so fixing the amount of permanent alimony as to encourage a penurious husband to give custody to the wife. In Smith v. Smith, 2 Phill. Ecc. 235, 16r Eng. Repr. II30 (I8I4), deduction for the support of a child which the husband had forcibly taken from the wife was refused. In Kempe v. Kempe, supra note $\mathrm{r} 2$, the court indicated to the husband that if the wife refused to take custody of the child, the court would be inclined to reduce the amount of alimony, but not if he refused to give custody to the wife.

${ }^{17}$ Otway v. Otway, supra note ro; Blaquiere v. Blaquiere, 3 Phill. Ecc. 258, x6I Eng. Repr. I319 (1820); Durant v. Durant, I Hag. Ecc. 528, I62 Eng. Repr. 667 (1826).

${ }^{15}$ Cooke v. Cooke, supra note I2; Smith v. Smith, supra note 16: ". . . perhaps it would be but just that where the husband violates the matrimonial engagement, and the fortune was originally belonging to the wife, that he should give back the whole of it-Courts, however, have not gone that length. . .."

10 “. . . it is due to the morals of society that a dissolute husband, who so offends (adultery with servant girl) should contribute liberally to the support of an injured wife." Kempe v. Kempe, supra note 12. See also Cooke v. Cooke, supra note 12; Street v. Street, 2 Phill. Ecc. I, 162 Eng. Repr. 196 (I814).

${ }^{20}$ Otway v. Otway, supra note ro (one-half after deduction for support of children); Cooke v. Cooke, supra note I2 (one-half, the court discussing several unreported decisions); Smith v. Smith, supra note 16 (one-half); Street v. Street, supra note I9 (about two-fifths); Kempe v. Kempe, supra note r2 (one-third, wife having custody of one child); Durant v. Durant, supra note I7 (about one-sixth).

${ }^{21}$ See Gooden v. Gooden, 65 L. T. 542, 543 (I89I).

${ }^{22}$ See, for instance, 2 Bishop, Marriage, Divorce ind Separation (I89i) \$863; Steward, Marriage and Divorce (1887) $\$ \$ 362,367 ; 3$ Blackstone, Comm. 94; Godolphin, Reportorium Canomictm (3d ed. I687) pp. 508, 509 .
} 
upon a pecuniary provision for the support of the guilty wife as a condition to granting the husband a divorce. ${ }^{23}$ That was a novel and significant development in the law of divorce flying in the face of the then accepted legal and moral dogmas. ${ }^{24}$ Alimony to the innocent husband seems never to have been suggested to the Ecclesiastical judges, but such an award would presumably have been also unthinkable because the wife was under no duty to maintain him.

Somewhat different considerations surrounded the problem of providing the wife with maintenance during the pendency of the proceedings, and with suit money. That an innocent wife must be placed in a position to obtain a separation or defend against the husband's false charges was readily apparent. Temporary alimony and suit money were accordingly ordered when reasonably necessary to enable her to prosecute or defend the divorce libel. ${ }^{25}$ The Ecclesiastical judges, however, did not lose sight of the fact that the marital delinquency of the husband was yet to be determined and of the danger that he be required to support a guilty wife or to provide her with funds with which to maintain a vexatious suit. If the wife had ample financial means, the allowance might be withheld. ${ }^{26}$ On the other hand, if the complaining husband was unable to furnish maintenance ${ }^{27}$ or failed to comply with the court's order, ${ }^{28}$ his action might be stayed. In any event it was said that the allowance should be smaller than permanent alimony. ${ }^{2 \theta}$ The nature of the accusation made apparently assumed considerable importance. ${ }^{30}$ As in the case of permanent

${ }^{23}$ MacQueEN, op. cit. supra note 3, at $537 \mathrm{ff}$.

34 "The Parliamentary practice of requiring the injured husband to make a provision for his delinquent wife had not much to commend it, either morally or legally. Morally it seems monstrous to compel a man to support through life the woman who has dishonored him; legally, she has no claim whatever, because after she has committed adultery, the husband may turn her out of doors. . . . What, therefore, can appear more strange than to call upon the husband to secure her maintenance? Yet this was constantly done in Parliament, sometimes in the upper but often in the lower assembly." MacQueen, Divonce and Matrimonial. Jurisdiction ( 1858 ) 55.

${ }^{25}$ See references, supra note 9 . The fact that the common law scheme of marital property rights left the wife economically helpless was emphasized. Wilson v. Wilson, 2 Hag. Cons. 203, 16x Eng. Repr. 716 (1797). Before temporary alimony was ordered, the marriage must have been admitted or proved. Smyth v. Smyth, 2 Add. 255, r62 Eng. Repr. 287 (1924); Mitchell v. Mitchell, I Sp. Ecc. 102, 164 Eng. Repr. 59 (1853). Usually, the temporary alimony was computed from the date of the return of the citation. Bain v. Bain, 2 Add. 286, $x 62$ Eng. Repr. 286 ( 1824 ). An allowance to the wife might be made pending appeal from a sentence against her. Lovedon v. Lovedon, I Phill. Ecc. 208, I6r Eng. Repr. 962 (1810). Following the ecclesiastical practice, Parliament frequently required the husband seeking a legislative divorce to provide the wife with funds to maintain her defense. MAcQuEEN, op. cit. supra note 3, 53 I ff.

${ }^{26}$ Wilson v. Wilson, supra note 25. See also the unreported decisions referred to in Beevor v. Becvor, 3 Phill. Ecc. 26r, I6r Eng. Repr. 3319 (1809).

${ }^{27}$ In Bruere v. Bruere, I Curt. Ecc. 566, I63 Eng. Repr. I98 (I837), temporary alimony was not granted because the complaining husband was an insolvent debtor, but the proceedings were stayed "until some small sum by way of maintenance is afforded to the wife."

${ }^{28}$ Bird v. Bird, I Lee 572, I6r Eng. Repr. 210 (I754) (nullity suit).

${ }^{20}$ Otway v. Otway, supra note 10; Smith v. Smith, 2 Phill. Ecc. 152, 161 Eng. Repr. 1105 (1813); Kempe v. Kempe, supra note ro.

${ }^{30}$ The application of a wife charged with adultery was not looked upon with complete tolerance. "Now, though the wife during the pendency of the suit must be presumed not to be guilty, yet she is not to live exactly in the same way as if she were exempt from any imputation: She is as it were under a cloud, and should seek privacy and retirement." Hawkes v. Hawkes, I Hag. Ecc. 526, 162 Eng. Repr. 666,667 (1828) (suggesting also that the courts "have in such cases been generally disposed to consider as a fair medium about one-fifth of the net income"). On the other hand, a charge of adultery made by 
alimony, the fact that the husband's wealth came from the wife, ${ }^{31}$ or that there were children to support, ${ }^{32}$ was of influence in determining the amount of the allowance. The issue as to temporary alimony was raised by an ancillary pleading called "allegation of faculties," in which the necessary averments of the wife's needs and the husband's means were made, which the husband was required to answer under oath. ${ }^{33}$

Under the Ecclesiastical law the wife was not entitled to permanent alimony after divorce a vinculo. ${ }^{34}$ The marital relationship upon which her right to support depended was declared never to have legally existed. She was then in the same position as any other feme sole to maintain herself. The more enlightened legislation today ${ }^{35}$ reflects the recognition that the practical effects of reliance upon the fact of marriage cannot be so easily ignored. The de facto wife, however, was given temporary alimony and suit money when defending a nullity action brought by the husband. ${ }^{36}$

The alimony order being designed primarily for maintenance and based upon a continuing duty to support, the Ecclesiastical judges felt free to modify the order as changed circumstances might warrant. ${ }^{37}$ The traditional method of enforcing the order was by the process of excommunication. ${ }^{3 s}$ The common law writ de estoveriis habendis was apparently also available. ${ }^{39}$ In an appropriate case, the Chancellor might assist by the issuance of the writ ne exeat Regno. ${ }^{40}$ When Parliament later forbade the use of excommunication for civil purposes, enforcement by contempt and sequestration with the cooperation of the High Court of Chancery was substituted. ${ }^{41}$

\section{Alimony under American Statutes}

Every American jurisdiction ${ }^{42}$ except South Carolina has a statute regulating the allowance of alimony to the wife in absolute divorce. In two states (Delaware, ${ }^{43}$

the wife was said to "give a complexion to the case." Rees v. Rees, 3 Phill. Ecc. 387,389 , I6r Eng. Repr. 1361,1362 (182r) (the court suggesting a different approach where the wife sues on the ground of cruelty "which frequently turns out a complication of equivocal facts where there are faults on both sides").

${ }^{31}$ Smith v. Smith, supra note 29.

${ }^{33}$ Brisco v. Brisco, 2 Hag. Cons. 199, I6I Eng. Repr. 714 (I8I6); Hawkes v. Hawkes, supra note 30.

${ }^{33} 2$ BuRn, op. cit. supra note 4, at 508; Poynter, op. cit. supra note 4, at 86; Brisco v. Brisco, 2 Hag. Cons. 199, I6r Eng. Repr. 714 (1816).

34 AUliffe, Parergon (I726) 59; Godolphin, op. cit. supra note 9, at 509; 2 Bishop, op. cit. supra note 2, \$885. In Bird v. Bird, I LEE 620, I61 Eng. Repr. 227 (x754) the one reported decision usually cited for the above proposition, the husband obtained a nullity decree based on the wife's former marriage of which fact she had knowledge at the time of contracting the second marriage.

${ }^{35}$ See I Vernier, AMierican Family Laws (I93I) $\$ 53$.

${ }^{30}$ Bird v. Bird, I Lee 209, 418, I6I Eng. Repr. 78, I54 (1753). See also Portsmouth v. Portsmouth, 3 Add. 63, r62 Eng. Repr. 404 (1826); Mills v. Chilton, I Rob. Ecc. 688, r64 Eng. Repr. II78 (I849).

${ }^{37} \mathrm{Cox}$ v. Cox, 3 Add. 276 , I62 Eng. Repr. 480 ( 1826 ) (temporary alimony in proceeding for restitution of conjugal rights reduced). See also De Blaquiere v. De Blaquiere, 3 Hag. Ecc. 322, 329, 162 Eng. Repr. 1173, II75 (1830); Neil v. Neil, 4 Hag. Ecc. 273, 162 Eng. Repr. 1446 (1832); PoynteR, op. cit. supra note 4 , at 89 .

${ }^{38} 2$ Burn, op. cit. supra note 4 , at $506 . \quad{ }^{30}$ I Blackstone, CoMm. $44 \mathrm{I}$.

103 Daniel, Plending and Practice of the High Court of Chancery (2d ed. $x 85$ ) 1996.

453 GEo. III, c. 127 (1812-13); 2 \& 3 WM. IV. c. 93 (I83I-32).

12 In this article American jurisdictions will include the forty-eight states, Alaska, District of Columbia and Hawaii. Absolute divorce is prohibited in South Carolina by S. C. Consr., Art. 17, \$3.

${ }^{40}$ Delatvare: REv. Code (1935) $\$ \$ 35 \times 1,3512$. On divorce for the husband's aggression the wife shall be allowed a reasonable share of his real and personal property. 
Texas ${ }^{44}$ ) the allowance is indirect and in the form of a division of property. In another (North Carolina ${ }^{45}$ ) the statute also authorizes a division of property but is fragmentary and obscure. In the remaining jurisdictions the following points will be considered: (I) whether permanent alimony is to be awarded before or after the final decree, or only in such decree; (2) whether the award is by the court or jury; (3) the statutory name or description of the award; (4) conditions of the award, such as guilt of the husband, need of the wife, etc.

Time of the allowance-Only three states ${ }^{46}$ expressly provide for an award of alimony after the decree. In nearly all the others the language is such that it seems to refer to the time of the decree only ${ }^{47} \mathrm{Tw}^{48}$ expressly time the alimony award with the interlocutory decree. Only one ${ }^{49}$ specifies a time before or at the decree.

Who makes allowance-The allowance of alimony is by the court in all jurisdictions except one.50

Statutory description of the award-It is interesting to note that of the forty-seven jurisdictions providing for an allowance to the wife, only thirty-two expressly describe it as alimony and only two denominate it "permanent." In nine states two descriptive words are used; one uses three, another four. Among the terms are "maintenance" (eleven jurisdictions), "allowance" (ten jurisdictions), "support" (three jurisdictions), and "recovery," "payment," "separate support and maintenance," "sum of money" (one each)..$^{51}$

Conditions of the award-The Ecclesiastical courts did not grant alimony to a wife divorced for her own misconduct, nor to one who was not in need of aid. Most American jurisdictions preserve the Ecclesiastical rule as to the guilty wife either by failure to change it or by express provision. A few jurisdictions have statutes which expressly or by implication permit the guilty wife to have alimony. ${ }^{52}$ Of course in those jurisdictions where the court may divide the property of the parties regardless of fault ${ }^{53}$ or where a part of the husband's property may be decreed to the guilty wife $^{54}$ some provision may be made for a destitute though guilty wife.

Revision of alimony-Since alimony in absolute divorce is a substitute for the wife's right to support by her husband it would seem that it should be subject to change as the need of the wife or the ability of the husband changes. This seems to be the rule of the Ecclesiastical courts in limited divorce cases and of the courts of a

"Texas: CoMpr. Stat. (I928) Civ. Code, art. 4638 . The court shall order a division of the estate of the parties in such a way as seems just and right, having due regard to the rights of each party and the children.

${ }^{40}$ North Carolina: CoDE (Michie, r927) \$1668.

${ }^{6}$ Massachusetts: Ges. Laws (1932) c. 208, \$34; New Jersey: Comp. Stat. (1910) p. 2035, \$25; Rhode Island: GEN. LAws (1923) \$4216.

${ }^{17}$ The language of the statute varies, but the following phrases are common: "Upon granting a divorce," "when a marriage shall be dissolved," "when a decree shall be entered," "where divoree is granted," "in the final decree," "on final hearing," etc. See 2 Vernier, American Family Laws \$ro5, Table LIII.

${ }^{8}$ Utah: Rev. Stat. (1933), 40-3-1, 40-3-5; Washington: Comp. Stat. (Remington, r922) \$988.

${ }^{40}$ New York: Crv. Prsc. Acr (Cahill, r93I) \$\$1155, 1170, I175.

${ }^{60}$ Georgia: ColE (1933) \$30-209.

612 Varmier, American Family Laws \$ro5, Table LIII.

${ }^{52} I d$. \$105. ${ }^{53}$ Id. $\$ 96$.

*Id. $\$ \$ 99$, 100. 
few American jurisdictions in absolute divorce. But the prevailing rule is that the court can not alter the decree after it has been made, unless power to do so was reserved therein, or unless there is statutory authority. In I886 Stimson found statutes giving such authority in only twenty states..$^{55}$ Today there are statutes authorizing revision in thirty-four. ${ }^{56}$ In nearly all of these revision is within the discretion of the court. Seven states, ${ }^{57}$ however, make revision mandatory in case of the wife's remarriage. Four of these have been passed in the last five years. In the states where statutes make revision of alimony discretionary with the court, specific circumstances are rarely mentioned. ${ }^{58}$

Form and amount of alimony-Of the fifty American jurisdictions awarding absolute divorce all but Texas have some express provision relating to the form and amount of alimony. In practically all of these the amount of alimony is left to the discretion of the court. In Georgia, ${ }^{58}$ however, the amount of alimony is fixed by the jury. Only two states ${ }^{60}$ fix an upper limit for the award.

In the other states the statutes restrict the discretion of the courts in two ways; by the use of rather vague defining terms or by directing the court to consider certain more or less specific considerations. The most frequently occurring defining term is "just" found in twenty-two jurisdictions. "Reasonable" occurs seventeen times; "suitable," eight; "proper," six; "equitable" five. Other words found in various statutes are: "fit," "necessary," "sufficient," "right" and "expedient."

Fourteen jurisdictions do not name any definite considerations by which the court is to be governed in fixing the amount. This is probably the best type of statute. The vague considerations named in many statutes are at best useless. They are even possibly dangerous in that they may be treated as narrowing the scope of the court's discretion by implication. The only matters mentioned with any frequency are the circumstances or situation of the parties (found in twenty jurisdictions). Other considerations mentioned are: all the circumstances of the case (eight jurisdictions), nature of the case (seven), ability of the husband (eight), character of the parties (five), the value of the husband's estate (four) etc. etc. ${ }^{61}$

"Stimson, AMerican Statute LaW (r886) \$626r.

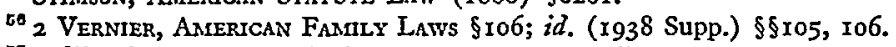

${ }^{57}$ California: Crv. Code (Lake, I937) §r39; Hawaii: Laws 1933, Spec. Sess., act 35, p. 48; Illinois: Rev. STAт. (Cahill, 193I) c. 40, §I9, am'd by Laws 1933, p. 492; Montana: Rev. Code (I935) \$577I; New Jersey: Laws 1933, c. 145, p. 296; New York: Crv, Prac. Acr (Cahill, I931) §II59; Wisconsin: STAT. (1935) \$247.38.

${ }^{88}$ Four states mention remarriage of the wife and one (New York) mentions financial inability of the husband. For reference to these statutes and for details of all revision statutes, see 2 VERNIER, AMERICAN FaMily Laws $\$$ Io6, Table LIV; id. (r938 Supp.) \$106. For cases on the effect of second marriage upon the obligation to pay alimony, see note, L. R. A. I915F. 820-23.

${ }^{50}$ Georgia: CODE (1933) \$30-209.

${ }^{60}$ In Louisiana, Crv. CoDE, art. I60, am'd by Laws 1928, p. 24 alimony shall not exceed one-third of husband's income. In Minnesota, GEN. STAT. (1923) $\$ 8602$, alimony must not exceed in aggregate with property awarded wife, in present value, one-third the personal estate and income and one-third the value of real estate of husband. In $x 886$ Rhode Island and Connecticut had similar restrictions. See Strmson, American Statute LaW $\$ 6262$.

${ }^{\circ 1}$ For the exact words used in each statute, sec 2 Vernier, American Family Laws §io7, Table LV; id. (r938 Supp.) §107. 
Most American statutes do not specify whether the alimony is to be paid in a gross sum or by stated instalments. Fifteen jurisdictions specifically provide that it may be by instalments, which is presumably the law also where the statute is not specific to the contrary. Fourteen jurisdictions $s^{62}$ specifically provide that the alimony allowance may be in gross. In most of these it is provided, however, that the court may award alimony in instalments or that a decree of a gross sum may be satisfied on the instalment plan. None of the statutes seem to make mandatory the payment of a gross sum.

Enforcement and security-That many husbands object to paying alimony can be fairly deduced from the number and variety of statutes providing for methods of enforcing the court's decree. At first glance it is surprising to find that eight states ${ }^{03}$ have no enforcement statutes expressly relating to divorce. Divorces, however, are usually granted by courts having equity powers and the usual remedies of the chancellor are generally available wherever divorces are granted. This discussion will be limited to statutes specifically relating to enforcement of divorce decrees. Forty-three states have such express statutes. They fall conveniently into three classes: those dealing with security for the husband's performance; those concerned with specific enforcement measures; and those conferring upon courts in divorce actions in express terms broad powers which most divorce courts probably have as courts of equity or law.

Security-Twenty-seven states ${ }^{64}$ provide in varying terms that the husband may be required to give security to abide by the decree. These statutes show certain minor

${ }^{62}$ Alasķa: Laws I923, p. 38 (in gross or instalments); Arizona: Rev. CodE (Struckmeyer, r928) $\$ 2187$ (in one sum, or in instalments); Connecticut: GEN. STAT. (1930) \$5182 (at stated periods with a definite amount fixed which may be paid in lieu of all instalments); Delaware: REv. CODE (I935) \$3512(16) (gross sum, or an annual allowance); Indiana: ANN. Stat. (Burns, I926) \$1111 (gross sum, not annual instalments, but court may give time for payment by instalments); Kansas: Rev. STAT. (I923) $\$ 60$ (15xx) (in gross or instalments); Maine: Rev. STAT. (1930) c. 73, \$9 (may be a specific sum to be paid wife, instead of alimony); Michigan: CoMp. Laws (1929) \$12745 (to be paid in gross or otherwise); Missoutri: Rev. Stat. (1929) \$I356 (may be in gross or from year to year); New Mexico: Stat. ANN. (1929) $\$ 68(506)$ (in single sum or in instalments); Ohio: CoMpl. GeN. Code (Page, 1931) \$11991 (in gross or instalments as equitable); Oklahoma: STAT. (193r) $\$ 672$ (in gross or instalments as is just and equitable); Oregon: CoDE (1930) $\$ 6$ (914) (in gross or instalments); Rhode lsland: Gen. LAws (1923) $\$ 4216$ (fixed sum or sums).

${ }^{63}$ Alabama, Delaware, Kansas, Louisiana, Nevada, South Carolina, Texas and Utah.

os Arizona: Rev. CoDE (Struckmeyer, 1929) (court may affix a lien on husband's property to secure payment); California: Crv. CODE (Lake, I937) \$r40 (court may require husband or wife to give reasonable security); Colorado: CoMp. LAws (x921) $\$ 5599$ (court may require sccurity to be given); Florida: REv. GEN. STAT. (I920) \$\$3195, 3198, 3200 (court may order security to be given); Hawaii: Rev. LAws (1925) \$298I (judge may require reasonable security); Idaho: CoDE (1932) \$3I-707 (court may require reasonable security); Illinois: REv. STat. (Cahill, r93I) c. 40, $\$ 19,2 I$ (reasonable security when wife is the complainant); Indiana: ANN. STAT. (Burns, 1926) $\$ \mathrm{IIrr}$ (if court allows payment in instalments, it must require security); Maine: Rev. STnT. (1930) c. 73, $\$ 9$ (may order assignment to wife for life of part of husband's real estate, or rents and profits); Massachusetts: GEN. LAws (1932) c. 208, $\$ \$ 12-14,25$, 36 (may order sufficient security when alimony is decreed to wife); Michigan: Comp. Laws (r929) \$12777 (party arrested for default in payment of alimony is to be discharged upon executing a bond with two sureties); Minnesota: GEN. STAT. (I923) $\$ 8604$ (court may require husband to give sufficient security and may decree a specific lien upon specified parcels of his real estate); Mississippi: Cone (1930) \$1421 (court may require sureties); Missouri: REv. STAT. (1929) $\$ \$ 1355,1356$ (husband may be ordered to give security); Montana: REv. CODE (I935) $\$ 5772$ (may require husband to give reasonable security); Ne- 
variations. ${ }^{65}$ In seven states the general rule that security may be required only where the wife obtains the decree is set out; in one, security is to be asked only when payment is to be by instalments; in another, only after the arrest of the husband for non-payment. Whether security is to be by bond or otherwise is generally left to the court's discretion. Ohio ${ }^{66}$ allows the court to withhold the decree of a successful husband until security is given.

Enforcement-There is a considerable variety in enforcement methods. ${ }^{67}$ In six states resort to some or all of such remedies is conditioned upon failure to give the security ordered, or upon default of such security. The remedy provided may affect: (I) property of the defendant; (2) his person. Among the remedies provided by statute against property are: sequestration, receivers, attachment, execution, trustee process and garnishment. In Missouri ${ }^{\mathrm{es}}$ a spendthrift trust is invalid against an alimony decree.

While an alimony decree is in some respects a money judgment, it is also an order by a court of equitable powers, and as such is usually enforceable against the husband's person. Although the statutes of many states are broad enough to include contempt as a remedy by implication, it is curious to note that only ten ${ }^{69}$ expressly mention contempt or imprisonment.

In the majority of states the enforcement statute is very general. It will be sufficient to give a few examples: ${ }^{70}$ Any other remedy applicable to the case (California), such order or decree as will secure the wife's alimony to her (Florida), any compulsory process deemed proper (Maine), same manner as decrees in equity are enforced (Massachusetts), such other lawful ways and means as are according to practices of the court (Missouri), etc. Only nine ${ }^{71}$ expressly provide for trustees who are to collect, receive, expend, manage or invest property or money ordered paid to or

braska: Comp. Star. (1929) $\$_{42}(323)$ (court may require sufficient security); New Hampshire: PuB. Laws (1926) c. $287, \$ 78$ (court may Iequire security); New lersey: Comp. STAT. (I9Io) p. 2035, $\$ 25$ (court may require reasonable security); New York: Crv. PRAc. Acr (Cahill, x93x) \$§II7I, xI7xa, II72 (court may require reasonable security, in such manner and at such time as it thinks proper); North Dakota: Cosip. Laws (1913) $\$ 4406$ (court may require reasonable security); Ohio: Compl. Gen. Code (Page, I93I) \$\$rr979(I), Irg95-6 (security, by bond or otherwise, to court's satisfaction); South Dakota: Comp. Laws (I929) §x66 (reasonable security); Vermont: GeN. Laws (I933) \$3I59 (sufficient security); Virginia: CODE (I930) \$5I07 (court may require security); West Virginia: CoDE (193r) c. 48, art. 2 , $\$ \$ 1_{3}, 15$ (may require security to abide any decree); Wisconsin: STAT. (I935) $\$ 247.30$ (sufficient security); Wyoming: Comp. Stat. (I93I) c. $35, \S$ II 8 (court or judge may require security).

${ }^{o r}$ See synopsis of provisions in note 23 , supra.

oo Ohio: CoMpl. Gen. Code (Page, 193I) \$\$Ir979(I), rx995.

o7 See details of enforcement statutes in 2 Vernier, AMrerican Family Laws §ro8, Table LVI and id. (1938 Supp.) 5 ro8.

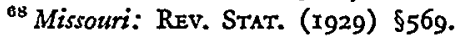

${ }^{00}$ Colorado: CoMr. Lsws (1921) \$5599; Connecticut: Gen. Stat. (1930) \$5182; District of Columbia: Code (1929) tit. 14, \$\$70, 7x; Iowa: CoDE (1935) \$r0482; Michigan: CoMp. Laws (1929) \$\$12779, 12780 (am'd Laws 1931, no. 232, p. 406); Minnesota: Gen. Stat. (I923) \$8604; Nebraska: Comp. Stat. (r929) \$28(462) (applies to alimony for support of children); New York: Crv. Prac. Act (Cahill, I93I) \$I72; Vermont: Gen. Stat. (I933) \$3172; Wyoming: CoגP. StAT. (I93I) \$35 (r20).

${ }^{70}$ For citations to and comparative wording of the statutes in all states, see 2 VERNIER, AMERTCAN FAMILY Laws $§ 108$, Table LVI; and id. (1938 Supp.) §108.

${ }^{71}$ See 2 Vernier, American Famaly Laws §ro8. The jurisdictions are: Alaska, Michigan, Minnesota, Nebraska, New Hampshire, Oregon, Vermont, Wisconsin, Wyoming. 
for the wife, and to pay the income or principal thereof to the wife, under the court's discretion. Michigan seems to be the only state providing a special action ${ }^{72}$ against a party ordered to pay alimony in another state. New York appears to be the only state making special provision ${ }^{73}$ for the enforcement of the decree against a defendant in hiding or out of the state. Recent amendments in Michigan and New York evince a tendency to restrict the use of contempt.

Alimony to the husband-If an allowance may be ordered paid by a wife to a husband in a divorce case, it is nevertheless a misnomer to call it "alimony," for alimony is a substitute for the common law duty of support. A wife owes her husband no such duty, except by statute in a few jurisdictions. It follows that a court may not grant alimony to the husband without statutory authority and such is the usual American rule. In 1886 Stimson $^{74}$ found two states which had statutes allowing alimony to the husband and three others which did not distinguish between the spouses in this regard. Today the statutes in fifteen jurisdictions authorize the granting of alimony to the husband and this does not include limited divorce statutes or statutes allowing the court to award part of the wife's property to the husband, unless the statutes expressly denominate such an award as alimony. ${ }^{75}$

Unsuccessful attempts have been made to persuade the courts to award alimony to husbands, based upon the theory that the married women's property acts, and other "equal rights" laws, have so equalized the property rights of the spouses as also to equalize their respective duties, including the duty of support. The answer of the courts has usually been that, in spite of such statutes the duty of support is still upon the husband alone, unless expressly imposed also upon the wife by statute, in which case, in a few instances, the husband has succeeded. ${ }^{76}$

Statutes which allow alimony, or something more strictly analogous to it than property awards are found in fifteen jurisdictions ${ }^{\mathbf{T 7}}$ today. Most of these statutes do

72 Michigan: CoMP. LAws (1929) \$12770.

${ }^{73}$ New York: Crv. PRAC. ACT (Cahill, I93I) $\$ \mathrm{Ir7I}$ (a). It is provided that where the defendant is out of the state or is in hiding, so that he can not be served, the court may order sequestration of his property, real or personal, tangible or intangible, within the state; appoint a receiver thereof, who may be the wife; or take possession by injunction or otherwise. The property or its income may be applied to alimony, temporary or permanent, suit money, etc.; and if it be insufficient, the mortgage or sale of real property may be ordered. The wife may be authorized to use and occupy and house, property or chattels of the husband.

" Stimson, American Statute Law (I886) \$6264.

${ }^{76}$ See note 77 , infra, for statutes of the fifteen states granting alimony to husbands. The effect of divorce on property rights is not within the scope of this article. For a collection and analysis of such statutes see 2 Vernier, American Family Laws $\$ \$ 96-102$; and $i d$. (1938 Supp.) \$\$96-ro2.

${ }^{73}$ See annotations Right of Husband to Alimony in Action for Divorce, r9 ANN. CAs. $\times 142$ (1911); and Right of Husband to Alimony, Maintenance, Suit Money or Attorney Fees in Suit for Divorce, 24 A. L. R. 491-99 (I923). See also comment in note (I923) 32 YALE L. J. 478, 483.

${ }^{77}$ Alaska: Comp. Laws (1933) \$3995-Whenever a marriage shall be dissolved, the court has power to further decree for the recovery of the party in fault, and not allowed the care of the children, such an amount of money, in gross or instalments as may be just and proper for such party to contribute to the maintenance of the other. California: Crv. CoDE (Lake, r937) \$137-Temporary alimony allowed husband. Illinois: Rev. STAT. (Cahill, 193I) c. 40, \$19 as am'd by Laws 1933, p. 492-The court may make such order touching alimony and maintenance of the husband as, from the circumstances of the parties and the nature of the ease, shall be fit, reasonable and just. Id. $\$ 16$, as am'd by Laws r935, p. 733-Suit money and temporary alimony are allowed the husband. Iosva: CODE (r935) \$10478-The court may order either party to pay the clerk a sum of money for the separate support, maintenance and suit money 
not call the allowance alimony. Many of them are halfway measures, being limited to temporary alimony, suit money, or in one instance to divorce for insanity. ${ }^{78}$

Temporary alimony and suit money-Temporary alimony, which is an allowance for the support of the wife by the husband (or, in a few states, of one spouse by the other) during the divorce litigation, differs from permanent alimony in that temporary alimony is an actual enforcement of a duty of support which exists because the marriage continues, while permanent alimony is awarded only when the marriage is dissolved and is a substitute for a duty of support which ended with the divorce. It would seem to follow that statutory authority is not required for a decree of temporary alimony. The question is not important, however, because all American jurisdictions granting divorce, except one, ${ }^{79}$ have statutes authorizing a decree for alimony or suit money, or both, pendente lite.

Temporary alimony (for support) and suit money (for expenses of litigation) were regularly granted by the Ecclesiastical courts under rules substantially followed in most American jurisdictions today. The award could be made to a wife who was defendant as well as to one who was plaintiff, but in the latter case she had to show that there was a marriage, and in either case that she was really in need, and that there were probable grounds for her success in the action, the theory being that she could not, if guilty of a matrimonial offense, require her husband to support her. The claim could be defeated by the husband by showing that the court had no jurisdiction of his person, that the wife was guilty of cause for divorce, that she was not in need, that he was unable to pay, etc. The making of the award, and its amount,

of the other. Massachusetts: GeN. Lnws (r932) c. 208, \$34-Upon a divorce, or upon petition at any time thereafter, the superior court may decree a part of the wife's estate, in the nature of alimony, to the husband. New Hampshire: PuB. LAws (1926) c. 287, \$19-Upon a decree of divorce the court may order that the husband shall have a part of the estate of the wife, in the nature of alimony, as justice may require. North Dakota: Comp. Laws (rgr3) $\$ \$ 4402,4403,4405$-Either party may be required to pay temporary alimony to the other; the court, when the divore is granted may compel either party to make allowance to the other for support. Ohio: Compl. Gen. Cone (Page, I93 I) \$\$II993, Ir994-On divorce for the wife's aggression, the husband shall be allowed alimony out of her estate; temporary alimony may be awarded to either party. Oklahoma: STAT. (I93I) \$670-Suit money may be awarded to either party pending suit, and to the husband specifically, upon divorce. Oregon: CoDE (1930) \$6-914-Temporary support, pending appeal, may be awarded to the party found not to be in fault; whenever a marriage is dissolved, the court may provide for the recovery from the party in fault of an amount of money for the maintenance of the other. Pennsylvania: Laws 1929 , act $430, \$ 45$-If the wife is petitioner and has suffcient means, the court or judge may provide for support of the insane husband, if the husband has not sufficient estate in his own right for his support. Utah: REv. STAT. (I933) $\$ \$ 40-3-3,40-3-5-$ Temporary alimony may be awarded to either party, when an interlocutory decree is made, the court may make orders in relation to the maintenance "of the parties." Vermont: PuB. LAws (x933) \$3142-Perhaps suit money may be awarded to the husband, the section reading, "Such order (on application of either party) in regard to temporary alimony and funds to support the wife and minor children, and maintain the litigation during the pendency of the libel, as is just." Virginia: CoDE (Michie, 1930) \$511I-Upon divorce the court may make further decree concerning the maintenance of parties, or either of them. Washington: Comp. Stat. (Remington, 1922) \$988-This section, though general in its terms, has been held not to justify an award of temporary alimony to the husband, State ex rel. Jacobsen v. Superior Court, r20 Wash. 359, 207 Pac. 227 (1922). West Virginia: CoDe (1931) c. 48, art. 2, \$15-Upon decreeing a divorce, the court may make further decree, as is expedient, concerning the maintenance of the parties or either of them.

${ }^{78}$ See Pennsylvania statute in note 77 , supra.

${ }^{70}$ Tennessee, which has no statute, nevertheless awards both temporary alimony and suit money. See Lishey v. Lishey, 2 Tenn. Ch. I (1873); Winslow v. Winslow, I33 Tenn. 633; I82 S. W. 24 I (1916). 
were in the discretion of the ordinary. Of course, a hearing on these matters is merely preliminary, and the wife need establish only a prima facie case, the very purpose of the application being to enable her to go to the trial upon the merits. The courts, as we would expect, are more inclined to grant temporary alimony than permanent, but do not show as great a liberality in fixing the amount.

The statutes generally confer power to make allowances for alimony and suit money pendente lite in rather broad terms, which do not materially affect the operation of the foregoing rules. Hence the further discussion of these statutes will be confined to a statement of general tendencies and certain interesting exceptions. ${ }^{80}$

The application for temporary alimony should, in theory, be made before the final decree is obtained, since the order enforces the duty of support and depends on the existence of the marriage. Probably none of the statutes change this rule, the language used being general, e.g., that application is to be made "pending suit," "during pendency of the action," "pendente lite," etc. The making of the award is discretionary in all jurisdictions, although a few statutes use words in single sections which seem to be mandatory, such as that the court "shall grant" etc. But even in these jurisdictions the statutes as a whole make it clear that the entire matter is discretionary, not merely as to the amount, but also as to making any award at all. Only a wife is entitled to temporary alimony and suit money. There is a recent tendency in a few states ${ }^{81}$ to authorize such allowances to the husband.

Suit money includes only the actual expenses of trial and counsel fees. This being so, we should expect to find that the statutes make it the court's duty merely to ascertain the amount of such expenses, and to determine the fact of the wife's necessity. Such is in fact the case. Of course, a proper preliminary showing must be made by the wife, just as when she asks for alimony pendente lite. In only three states is the allowance called suit money. The nature of the allowance is made clear by the designation of its purpose.

The states which authorize an award of temporary alimony to the husband, also allow him suit money. Provisions for the enforcement of permanent alimony decrees have already been discussed. These provisions are worded so generally that they usually apply to awards of temporary alimony and suit money also. However most of the statutes authorizing temporary alimony and suit money have special sections relating to enforcement.

Transfers of property in fraud of alimony-Alimony must come from one of two sources-the property or the income of the husband. Recalcitrant husbands sometimes attempt to dispose of or encumber their property and thus defeat the allowance of alimony. To prevent this many states have passed statutes. These statutes take two forms: provisions for injunctions against disposing of property, and provisions rendering such disposition void as against claims for alimony. Statutes expressly authorizing injunctive relief have been found in seventeen jurisdictions. Conveyances

\footnotetext{
${ }^{80}$ For a detailed comparison of the statutes, see 2 Vernier, AMERICaN Family Laws $\{$ IIo, Table LVII; and id. (r938 Supp.) \$rro. 
in fraud of alimony are expressly voided by the statutes of five states. These, with certain other statutes designed to facilitate control of property, so that it may be available to meet the alimony decree are summarized in a note below. ${ }^{\mathbf{8 2}}$

${ }^{83}$ Alaska: Cosp. Laws (r933) \$3994-Court may enjoin disposition of property of either party pending suit. Arizona: REv. CODE (I928) $\$ \$ 2185,2186$-After the action has been brought, the husband shall not dispose of the community property, and any alienation made by him after that time shall be null and void, if made with a fraudulent intent of injuring the rights of the wife. At any time during the action the wife may require an inventory of all community property, and of her separate property, and may obtain an injunction against the husband's disposing of any of it. The court may make such temporary orders, during the pendency of the action, respecting the property of the parties, as may be necessary. District of Columbia: CODE (1929) tit. $14, \$ 70-$ The court may enjoin any disposition of the husband's property made to avoid the collection of allowances of temporary alimony and suit money, and of permanent alimony. Florida: REv. GEN. STAT. (r920) \$3198-If the husband is about to remove himself or his property from the state, the court may award a ne exeat or injunction against him or his property. Georgia: Cope (1933) \$30-112-After separation, no transfer of property made by the husband, except: bona fide, in payment of existing debts, shall pass the title so as to avoid the vesting thereof according to the final verdict of the jury. Kansas: Rev. STAT. (r923) $\$ 60(1507)$-After a petition has been filed, the court may make such orders to restrain the disposition of the property of the parties, or either of them, as may be proper. The probate judge may so order in case of the absence or disqualification of the district judge, and may modify his own orders in this respect, but not those of the district judge. Kentucky: STAT. (Carroll, I922) $\$ \S 2124,2126-$ When the husband is about to remove himself or his property out of the state, or there is reason to suspect that he will fraudulently sell, convey or conceal his property, the wife may obtain orders to secure alimony for herself and maintenance for her children without giving surety. Sales and conveyances to a purchaser with notice, or for the benefit of any religious society, in fraud or hindrance of the right of wife or child to maintenance shall be void as against them. Lauisiana: Clv. CoDE, arts. 149, 150, 15I-During the suit for separation the wife may, for the preservation of her rights, require an inventory and appraisement to be made of the movables and immovables in her husband's possession, and an injunction restraining his disposing of any part thereof, in any manner. From the day on which the action is brought, it shall not be lawful for the husband to contract any debt on account of the community, nor to dispose of the immovables belonging to the same, and any alienation by him after that time shall be null, if it be proved to be made with the fraudulent view of injuring the right of the wife. The rule is the same in divorce actions. Massachusetts: GEN. Laws (I932) c. 208, $\$ \$ 12-I 4-$ The husband's property may be attached pending suit. Nevada: CoMp. Laws (1929) \$9463-If after the filing of the petition, it seems probable to the court or judge in vacation that either party is about to do any act that would defeat or render less effective any order the court might ultimately make concerning property or pecuniary interests, an order shall be made for the prevention thereof, to be enforced as preliminary orders are enforced respecting children. New Hampshire: PUB. LAws (1926) c. 3I7, §I5Libelee's property may be attached pending suit. New Mexico: Stat. AnN. (I929) \$68(506)-The court may restrain the use or disposition of the property of either party, and enforce its order by attachment or otherwise. North Carolina: CoDe (1927) $\$ 1666$-If the husband is about to remove or dispose of his property, for the purpose of defeating the wife's claim for alimony, notice to him of the wife's claim of temporary alimony is not required. Ohio: Compl. GEN. Code (Page, I93I) \$II996-When it appears to court or judge in vacation that a party is about to dispose of or encumber property, so as to defeat the other in obtaining alimony, an injunction may be allowed to prevent this with or without bond. Oklahoma: Stat. (I93I) $\$ 67^{0}-$ After petition has been filed, the court or judge thereof in vacation may make and enforce by attachment orders to restrain the disposition of the property of the parties, and for the use, management, and control thereof. Texas: CoMpl. STAт. (I928) arts. 4634, 4635, 6840-On and after the day on which suit is brought, it is unlawful for the husband to contract debts on account of the community, or to dispose of community lands; any alienation made by him thereafter is null and void, if it be proved to be made with a fraudulent view of injuring the wife's rights. At any time during the suit the wife, to preserve her rights, may require an inventory and appraisement of both real and personal estate in the husband's possession, and an injunction against his disposing of any of it in any manner. Sequestration may issue at any time before final judgment, when the wife who is suing makes oath that she fears her husband will waste her separate property, or the common property, or the fruits of either, or that he will sell or dispose of same so as to defraud her of her rights, or remove same from the county during suit. Vermont: PUB. LAws (I933) \$3I43-The libelee, upon the application of either party, in any proceeding under the divorce chapter, may be enjoined from conveying, concealing or interfering with the property of the libelant, or from interfering with the possession, etc. of property held by either and claimed by the other. The court may make mandatory orders in connection with the property of the 
Alimony in limited divorce-Limited divorce, more commonly known as divorce from bed and board or divorce a mensa et thoro, is the divorce of the English Ecclesiastical courts. Its primary effect was to destroy the right of cohabitation; its chief characteristic, that it did not destroy the marriage. Though often and justly criticized $^{83}$ the number of American jurisdictions granting limited divorce is on the increase. In 1886 Stimson $^{84}$ found only twenty jurisdictions which granted such divorce. Today there are twenty-six. ${ }^{85}$ This does not include states authorizing separate miaintenance decrees by statute. ${ }^{86}$

Express statutory authority is essential to the power to grant divorce from bed and board. It is probably true, however, that when a court is empowered to grant divorce from bed and board, the power to award alimony is included by implication. It should also be borne in mind that divorce statutes are so phrased and arranged as to make it fairly clear that ancillary provisions apply to both absolute and limited divorce. It is therefore not surprising to find that in many limited divorce jurisdictions, statutes specifically relating to alimony are either lacking or very sketchy. To get a complete picture one must look to the decisions and to the statutes relating to absolute divorce.

In all jurisdictions authorizing limited divorce an innocent wife may obtain alimony. In general the same rules and limitations apply as in case of absolute divorce. In only five states is the award of alimony expressly limited to an innocent wife, or

parties and the children, and may enjoin either party from conveying or removing from the state, pending the libel or motion, such part of his or her property, as the judge considers necessary to secure alimony to be decreed, or make orders concerning the rights of either party, or any order that may be made pending such libel. Virginia: CODE (1930) \$5107-Court, pending suit, may make any orders proper to preserve the estate of the husband, so that it may be forthcoming to meet any decree made. Washington: Comp. STAT. (Remington, I922) \$988-Court has power, at all times, to grant any and all restraining orders necessary to protect the parties and secure justice. West Virginia: CoDe (193r) c. 48, art. 2, 513-The court or judge in vacation may make any proper order to preserve the estate of the husband, so that it may be forthcoming to meet any decree which may be made in the suit. Wisconsin: STAr. (I935) \$247.23 -The court may, pending the action, make necessary and proper orders in relation to the property of the parties. Wyoming: Rev. STAT. (1931) $\$ \$ 35-119$-If it appears, after filing petition, to the court or judge in vacation that either party is about to do an act which would defeat or render less effectual any order which the court might ultimately make in regard to property or pecuniary interests, an order shall be made for the prevention thereof, and such legal or equitable process issued as the court decms necessary or proper.

${ }^{83}$ See 2 Vernier, AMerican Fanily Laws \$II4.

84 Stimson, AMerican Statute Law (I886) \$\$6280, 6301, 6304 (1886).

${ }^{85}$ Alabama: Code (1923) \$7423; Arizona: Rev. Code (1928) \$2189; Arkansas: Dig. StAт. (Crawford \& Moses, I921) \$3500; Delaware: Rev. CoDE (1915) \$3005; District of Columbia: Code (x929) it. $14, \S 63$; Georgia: Code (Michie, 1933) \$\$30-10r; Hawaii: Rev. Laws (1925) \$\$2915, 2987; Indiana: Aws. Stat. (Burns, I926) \$1122; Kentucky: STAт. (Carroll, 1922) \$2121; Louisiana: Civ. Codz, art. 138; Maryland: ANN. CoDe (Bagby, 1924) art. 16, \$39; Michigan: Comp. Laws (1929) \$12729; Minnesota: Gev. Stat. (1923) \$8608; Montana: Rev. Code (1935) \$5736; Nebraska: Comp. Star. (1929) \$42(302); New Hampshire: PuB. Laws (1926) c. 287, \$24; Neqv Jersey: Comp. St. (1910) p. 2028, \$3; New York: Crv. Prsc. Act (Cahill, 193I) \$I161; North Carolina: Code (1927) \$1660; North Dakota: Laws 1927, c. 132; Pennsylvania: Laws 1929, act 430, \$11; Rhode Island: GeN. Laws (1923) \$4129; Tennessee: CODE (1932) \$8427; Vermont: PuB. Laws (1933) \$3130; Virginia: Code (Michic, 1930) \$5ro4; Wisconsin: STAT. (1935) \$247.04.

${ }^{80}$ For the statutes of thirty-nine jurisdictions allowing separate maintenance decrees, see 2 VERNIER, AMERICAN FaMtLy Laws \$139. 
to a wife who is petitioner. Possibly, in the others the grant of alimony will be confined to an innocent wife in accordance with the Ecclesiastical practice.

A limited divorce will confer upon the husband no right to be supported by his wife which he did not have by virtue of the marriage. Therefore if he is to have alimony or something akin to it, statutory authority for the award is as necessary as it is in cases of absolute divorce. Seven states have statutes under which alimony might be awarded to a husband in a limited divorce action. ${ }^{87}$

Limited divorce statutes make no significant changes in the form and amount of alimony. It is probably safe to say that the same considerations govern in limited as in absolute divorce. In one case the decree enforces the husband's duty of support; in the other, it is a substitute for that duty. In two states ${ }^{88}$ only is there a definite limit on the amount of alimony, and in both the limit is set at one third the annual net income of the party against whom the alimony is decreed.

Temporary alimony and suit money in limited divorce is governed by the same principles as govern such an award in absolute divorce. Only eleven ${ }^{89}$ of the twentysix limited divorce jurisdictions have statutes in reference to temporary alimony which apply specifically to limited divorce. Since none of them even purports to make any significant changes in the rules applied in absolute divorce cases further comment is unnecessary.

Schouler declares ${ }^{90}$ that a statute applying to divorce means an absolute divorce and not one from bed and board. A perusal of the statutes themselves makes it clear that many such statutes were meant to apply to both types. Therefore the searcher should always, when seeking a statute dealing with a point in limited divorce, look to see if there is a statute applying to "divorce" which will cover limited divorce as well. Due to the paucity of applicable decisions and to lack of clarity in the statutes many points are left in doubt.

In conclusion-Two questions remain: (I) what changes have been made in the Ecclesiastical court rules by statutes relating to alimony; (2) do present-day statutes evince any tendency to change older statutory rules?

The most fundamental change made by statute in the Ecclesiastical court system of rules was to make alimony payable where the marriage is totally dissolved. This change was fundamental because alimony was an enforcement of the duty of support: yet it is now applied by statute after the relationship out of which the duty arises is totally dissolved. The second change in Ecclesiastical court rules is the

${ }^{87}$ Indiana: ANn. Stat. (Burns, 1926) §1124; New Hampshire: Pub. Laws (1926) c. 287, \$25; North Carolina: Code (Michie, 1927) \$1665; North Dakota: Laws (1927) c. 132, p. 167, \$\$2, 3, 4; Rhode Island: GeN. Laws (1923) \$4219; Vermont: PuB. Laws (1933) \$3131; Virginia: Code (I930) §III.

${ }^{88}$ North Carolina: CoDE (Michie, 1927) §1665; Pennsylvania: Laws 1929, act 430, $\$ 45$.

80 Alabama: CODE (1923) §7424; Arizona: Rev. CODE (I928) §2r9r; Kentucky: Stat. (Carroll, I922) \$2121; Louisiana: Crv. Cone, art. I48, as am'd by Laws 1928, p. 164; Michigan: Comp. Laws (1929) §\$12735, 12773; Minnesota: Gen. Stat. (I923) \$\$8593, 8612; Nebraska: CoMp. Stat. (I929) 542(308); New Hampshire: Pus. Laws (1926) c. 287, \$25; New York: Crv. Prac. Act (Cahill, I93I) §1x69; North Carolina: CoDE (Michie, I927) §1666; North Dakota: Laws 1927, c. 132, p. 167, \$2.

${ }^{\circ} 2$ Schouler, Markiage, Divorce, Separation and Domestic Reiations, (6th ed.) \$545. 
authorization of alimony either permanent or temporary to husbands. The third is the allowance of alimony to guilty wives. These last two changes are recent and not universally adopted, but both are to be commended. Other changes made by statute seem to be minor in character, such as allowance of alimony in gross and various changes in procedure.

Comparing today's statutes with earlier ones relating to alimony, at least three significant tendencies appear. The first two, viz., authorizing alimony to the husband and allowance of alimony to guilty wives, have already been mentioned as they also represent fundamental changes in the Ecclesiastical court system of rules. The third significant change in present statutes over earlier ones relates to revision of alimony decrees. This change manifests itself in two ways: ( $\mathrm{I}$ ) courts are in general being given greater freedom to revise decrees; (2) in one situation, viz., remarriage of the wife, the most recent statutes make revision or cessation of alimony mandatory. On the whole, the changes made by statute in the Ecclesiastical system and the changes made by late statutes over older statutes are to be commended. 